\title{
215 再生軟骨モデルの組織構造形成に対する培養条件の影響（第 2 報） Influence of Culture Conditions on Regenerated Tissue Structure in Chondrocytes-Agarose Construct (Part2)
}

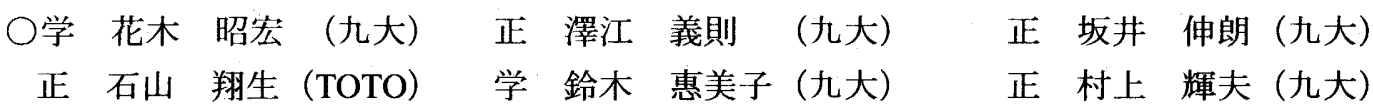

Akihiro HANAKI, Kyushu University, Motooka744, Nishi-ku, Fukuoka 819-0395 Japan Yoshinori SAWAE, Kyushu University, Nobuo SAKAI, Kyushu University, Sho ISHIYAMA, TOTO Emiko SUZUKI, Kyushu University, Teruo MURAKAMI, Kyushu University

Key Words: Chondrocyte, Extra-cellular matrix, Mechanical property, Dynamic mechanical loading, Tissue

\section{1. 粕 謇}

損傷した関節軟骨の治療法として注目される再生軟骨は，本来 の軟骨組織が持つ潤滑や荷重支持などの力学的機能を，現時点で は十分に再建できていない，軟骨組織の力学的機能は，軟骨細胞 が産生する細胞外マトリックスが組織構造を形成することにより 発現する ${ }^{(1)}$. また細胞外マトリックス(プロテオグリカンおよびI 型コラーグン)の産生は, 軟骨細胞に周期的な力学的負荷が与えら れると促進される事が報告されている(2).

そこで本研究では，2軸負荷培養装置 ${ }^{(3)}$ を用いてアガロースゲル を3次元スキャフォールドとした再生軟骨モデルに力学負荷を加 え，細胞外マトリックスの産生および組織構造形成と，それに伴 う力学特性の変化に対する培養条件の影響を検討した。

\section{2. 实殹方法}

\section{2-1 試倹片作型}

本研究では，牛中指骨遠位端の軟骨組織から酵素消化法 ${ }^{(4)} に よ$ って単離した軟骨細胞を4wt\%のアガロースダルに播種し，それを 再生軟骨モデルとして用いた. 再生軟骨モデルの形状は一辺 $5 \mathrm{~mm}$ の立方体と, 直径 $3 \mathrm{~mm} \times$ 高さ $2.5 \mathrm{~mm}$ の円柱形の 2 種類とした. 作製 した再生軟骨モデルはDulbecco's Modified Eagle's Medium (DMEM) にFoetal Bovine Serum (FBS) を20vol\%加えたものを培養 液として, $37^{\circ} \mathrm{C} の \mathrm{CO}_{2}$ インキュベータ内で一日静置培養した. そ の後, 立方体モデルは繰り返し力学的負荷を与えながら培養する 負荷群と比較対象のコントロール群，そのまま静置培養をする静 置群とに分けた. 円柱形モデルは静置群のみとした。

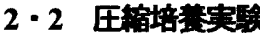

作製した2軸負荷培養装置のスライダー先端に塩化ビニール製 の圧子を取り付け，再生軟骨モデルに繰り返し単軸圧縮を加えな がら培養する実験を行った．実験は24ウェルのカルチャープレー 卜(FALCON)内て培養中の再生軟骨モデルに対して行った.

立方体モデルの負荷群には，周期 $1 \mathrm{~Hz} の 15 \%$ 単軸王縮ひずみを1 日6時間与えた. その日の負荷終了後は, 圧子を軟骨モデルの上面 に接触させたまま，ひずみ無しの状態 $(\varepsilon=0)$ とした，圧子が接触 している影響を評価するために，コントロール群にもモデル上面
に別の圧子を接触させて培養した. 円柱形モデルはカルチャープ レート内で静置培養を続けた. 培養液は2 日に1度, 全て交換した.

\section{$2 \cdot 3$ 力学試験}

培養した再生軟骨モデルは，培養1日目，8日目，15日目，22日 目に，高精度ロードセルを備えた力学試験機(AUTOGRAPH, SHIMAZDU)を用いて圧縮試験を行い，培養による弾性係数の変 化を測定した．試験片を培養液で満たした35mmディッシュ (FALCON)中に，培養時と力学試験時の圧縮方向が一致するよう に静置し，20\%/minの速度で10\%のひずみを与えた。この時, 直線 近似が可能であったひずみ $5 \%$ 10\%の応力ーひずみ曲線の傾き より, 弾性率を求めた. また試験片は著しい灾力緩和を示すため, ひずみ負荷後変位を保持し，応力が平衡に達したとみなされた 30 分後の応力を計測し，この值より平衡弾性率を求めた.

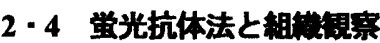

力学試験を行った試験片について，蛍光抗体染色法によって軟 骨細胞の代謝により細胞周囲に形成された細胞外マトリックスの 3次元組織構造を観察した.

試験片より圧縮方向と垂直に厚さ0.5mm程度の薄片を複数枚切 り出し, 蛍光観察の標本とした. 標本はプロテオグリカンの構成 成分であるケラタン硫酸を観察する群と，II型コラーゲンを観察 する群の2群に分け, それぞれ選択的に染色した. 染色後の標本は, 共焦点レーザー影微鏡(CLSM,BIORAD)上で60倍の油浸対物レン ズを用いて観察し，細胞外マトリックスにより形成された組織構 造の形態を評価した。

\section{$2 \cdot 5$ プロテオグリカンの定里}

力学試験後の試験片は-30度で冷涷保存し, 後日, 再生軟骨モデ ル中に含まれるプロテオグリカンの定量を行った(5).

凍結した試験片を2.8mMのエチレンジアミン四酢酸(EDTA)と $9 \mathrm{mM}$ の塩酸システインを加えたリン酸緩衝液(PBS)1mlに入れ, 完 全に溶解するまで $70^{\circ} \mathrm{C}$ ヒーター内で加熱した. 試験片が溶解し た㲘濁液は37゚Cのインキュべータ内で除熱した後, 3IUのパパイン (Papain from Carica papaya 76220,Fluka)を含むPBS溶液 $5 \mu \mathrm{l}$ と 1IU/ml のアガラーゼ( $\beta$-Agarase,Wako) $10 \mu$ 1を加え，インキュベータ内で 
一晚 $37^{\circ} \mathrm{C}$ に保温した. 翌日 $60^{\circ} \mathrm{C}$ で再加熱した後, ジメチルエチ レンブルー溶液で染色し，マイクロプレート測定装置(BIORAD) を用いた吸光度測定によりプロテオグリカン量を定量した.

\section{3. 实䑶拮果およひ考宗}

図1に力学試験によって得られた立方体モデルの弾性率を示す. 横軸は培盖日数を表している. 培養8日目ではコントロール群と負 荷群に明確な差は無いが, 培盖15日目では負荷群の弾性率が有意 に増加している. 培養22日目に減少した負荷群の弾性率には，長 期間の培養中にカビや雑菌が混入・増殖するコンタミネーション が発生した影響を含んでいると考えられる. また, 図2に定量試験 で測定された立方体モデルのプロテオグリカンの含有量を示す. 縦軸は試験片の湿潤重量に対するプロテオグリカンの重量比率を 表している. 図2において負荷群のプロテオグリカン含有量は培養 日数に応じて增している. 一方コントロール群は培養15日目に減 少を，22日目に大幅な増加を示している.

図1 と図2を比較すると, 培養8日目から15日目にかけて負荷群の プロテオグリカン量と弾性率の増加が同時に起こるなど, プロテ オグリカン量と弾性率が似た変化の傾向を示しているため, 両者 の間に何らかの相関があると考えられる. しかし，2つの值の増減 が完全には一致していないので, 弾性率がプロテオグリカンの量 で一義的に決定される訳ではないと分かる.

他方, 再生軟骨モデルの形状による細胞外マトリックスの組織 構造形成に対する影签を見るために，静置群の立方体モデル(a)之 円柱形モデル(b)の培養8日目における II型コラーダンの染色画像 を図3に示す. (b)においては再生軟骶モデル中の細胞間にI型コラ 一グンのネットワークが形成されているのが確認できるが，(a)で は見られない：これは円柱形モデルの表面積と体積の比が立方体 モデルの1.5倍あり，拡散による物質の十分な供給に有利な条件と なっているため, 良好な代謝によって細胞外マトリックスがより 多く産生されたためと考えられる. 同時に静置群の立方体モデル と円柱形モデルの弾性率を測定・比較すると, 8日目では円柱形モ デルの弾性率が立方体モデルよりも上昇しており，立方体モデル でも組織構造が確認できる15日目には両者の差は無くなっている. この事から II型コラーゲンの組織構造が形成されると, 弾性率が 上昇すると考えられる.

今後は円柱形モデルのプロテオグリカン量を測定して, 細胞外 マトリックスの産生量の増加を定量的に確認する必要がある. ま た円柱形モデルを用いて圧縮培養試験を行い，立方体モデルでは 明確には確認できなかった細胞外マトリックスの組織構造形成に 対する压縮負荷の影響を調べていく予定である.

\section{4. 结 吾}

本研究では, 力学的負荷下で培養した再生軟骨モデルについて, プロテオグリカン含有量および細胞外マトリックスの組織構造形 成と弾性率の相関関係を評価し，それに対する培羕条件の影響を 検討した. その結果, 再生軟骨モデルの弾性率の変化は, モデル 中のプロテオグリカン含有量の増加が一因になると考えられる.

一方でモデル形状を変更した実験を行い，細胞への物質供給が良 好なモデル形状のほうが， I型コラーゲンを中心とした細胞外マ トリックスの組織構造形成が促進され，弾性率の上昇に寄与する 事を確認した.

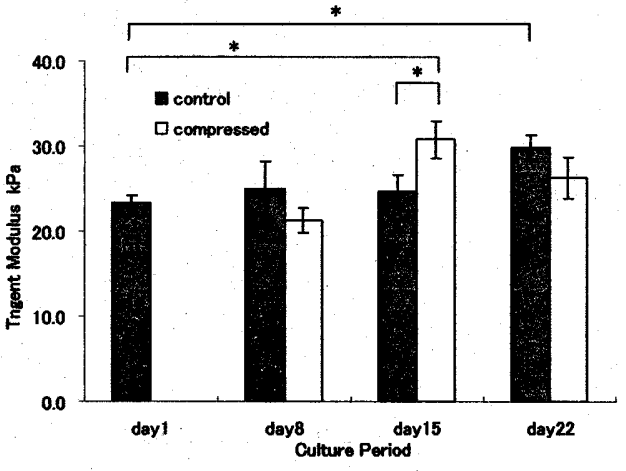

Fig.1 Tangent Modulus of Cube Model $(n=4, *: p<0.01)$

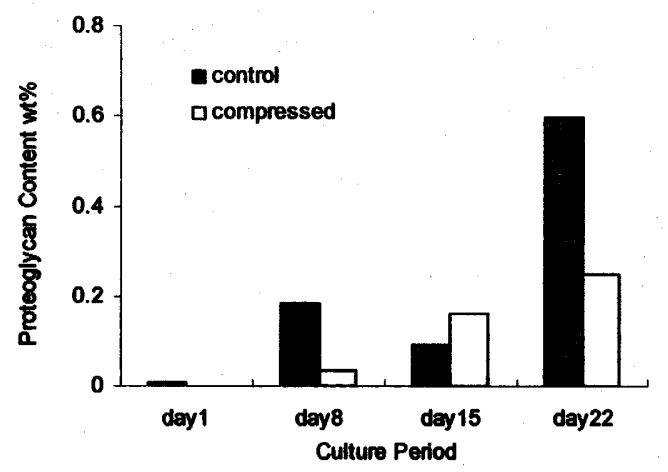

Fig.2 Proteoglycan Content in Cube Model

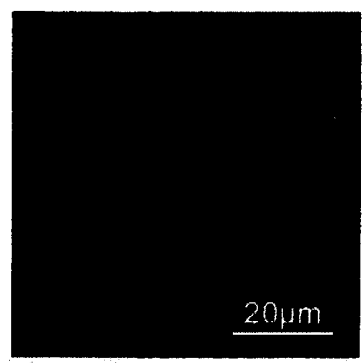

(a) cube

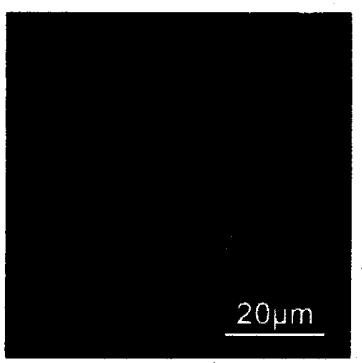

(b) cylinder
Fig.3 Confocal Image of Collagen typell elaborated around Chondrocyte cultured for 8 days

今後は円柱形モデルでも圧縮培養試験を行い，弾性率やプロテ オグリカン量を測定し，組織構造形成に対する圧縮負荷の影響を さらに調查していく予定である.

\section{考文虾}

(1) 花木, 石山, 澤江, 村上, 平成16年度日本工ム・イー学会九州 支部学術講演会論文集, (2005), 11

(2) Lee D.A. and Bader D.L., Biorheology, 37(2000), 149-161

(3) 花木, 澤江, 坂井, 石山，村上，2005年度年次大会講演論文集 Vol.5, (2005), 211-212

(4) Knight M.M., Lee D.A. and Bader D.L., Biochimica et Biophysica Ata 1405,(1998),67-77

(5) Lee D.A and Bader D.L., The Journal of Orthopaedic Research Vol.15, no.2, (1997), 181-188 